NBER WORKING PAPER SERIES

\title{
CORRESPONDENT CLEARING AND THE BANKING PANICS OF THE GREAT DEPRESSION
}

\author{
Gary Richardson
}

Working Paper 12716

http://www.nber.org/papers/w12716

\author{
NATIONAL BUREAU OF ECONOMIC RESEARCH \\ 1050 Massachusetts Avenue \\ Cambridge, MA 02138
}

December 2006

I thank colleagues, friends, and participants in the conference Economics of Payments II for comments and advice. I thank Francesca Labordo for exceptional research assistance. National Science Foundation Grant D/SES-00551232 supported this research. The author may be reached via email at garyr@uci.edu. The views expressed herein are those of the author(s) and do not necessarily reflect the views of the National Bureau of Economic Research.

(C) 2006 by Gary Richardson. All rights reserved. Short sections of text, not to exceed two paragraphs, may be quoted without explicit permission provided that full credit, including $\odot$ notice, is given to the source. 
Correspondent Clearing and the Banking Panics of the Great Depression

Gary Richardson

NBER Working Paper No. 12716

December 2006

JEL No. E42,E44,E65,N1,N12,N2

\begin{abstract}
$\underline{\text { ABSTRACT }}$
Between the founding of the Federal Reserve System in 1913 and the depression of the 1930s, three check-clearing systems operated in the United States. The Federal Reserve cleared checks for members of the system. Clearing houses cleared checks for members of their organizations. Correspondents cleared checks for all other institutions. The correspondent-clearing system was vulnerable to counter-party cascades, particularly because accounting conventions overstated reserves available to individual institutions and the system as a whole. In November 1930, a correspondent system in the center of the United States collapsed, causing the closure of more than one hundred institutions. Bank runs radiated from the locus of events, and additional correspondent networks succumbed to the situation. For the remainder of the contraction, banks that relied upon correspondents to clear checks failed at higher rates than other banks. In sum, weaknesses within a check-clearing system played a hitherto unrecognized role in the banking crises of the Great Depression.
\end{abstract}

Gary Richardson

Department of Economics

University of California, Irvine

Irvine, CA 92697-5100

and NBER

garyr@uci.edu 


\section{Introduction}

During the Great Depression, banks failed in larger numbers than at any other time in United States history. Nearly one-third of the depository institutions in operation at the onset of the downturn disappeared during the contraction. Bank failures often occurred in clusters characterized as crises. The first crisis of the depression began in Tennessee in the fall of 1930 and engulfed hundreds of banks in neighboring states. The final crisis began in Michigan in the winter of 1933, when to forestall runs on financial institutions, the governor ordered the state's banks to suspend operations. Neighboring states followed Michigan's example, igniting a chain reaction of state moratoria that forced President Roosevelt to declare a national banking 'holiday.'

Economists have long debated the reasons for the banking system's collapse. A traditional school of scholarship maintains that the underlying causes were withdrawals of deposits, illiquidity of assets, and the Federal Reserve's reluctance to act (Friedman and Schwartz, 1963; Elmus Wicker, 1996). A contending school concludes that banks failed because the economy contracted. Asset prices fell. Loan default rates rose. Banks became insolvent. These fundamental forces accentuated a process of bank liquidation and that began during the 1920s (Temin, 1976; Charles Calomiris and Joseph Mason, 2003).

These opposing views exist for many reasons. A principal one is differences in data sources. Scholars in the traditional school analyze data aggregated at the national or regional level. This data reveals bank failures clustered in space and time, often coinciding with turning points in macroeconomic time-series such as indices of industrial production, the money supply, the money multiplier, interest rates, and the deflation rate. Narrative sources from the 1930s characterize these clusters as banking panics. Scholars in the second school analyze data at lower 
levels of aggregation, or disaggregated data consisting of samples of national banks, or panels of banks from within individual cities, states, or Federal Reserve districts. Eugene White (1984) pioneered this line of research by examining a panel of data drawn from national banks. The most recent and comprehensive work (Calomiris and Mason, 2003) analyzes a panel of data for all Federal Reserve member banks. These different data sources provide different perspectives on various segments of the banking industry, but none provides a comprehensive view of the causes of failure for all types of banks operating in the United States throughout the contraction of the early 1930s.

This essay examines a new source of evidence that provides such a comprehensive perspective. The new source indicates the cause of suspension for all banks - including Federal Reserve members and nonmembers, national and state, incorporated and private - that suspended operations from the onset of the contraction in 1929 and until the national banking holiday in March 1933. The source comes from the archives of the Federal Reserve Board, whose Division of Bank Operations tracked changes in the status of all bank operating in the United States, analyzed the cause of each bank suspension, and recorded its conclusion and financial information for each bank on the St. 6386 series of forms. The complete series of St. 6386 forms survives in the National Archives of the United States (See Richardson (2005) for details).

This new source indicates that check-clearing systems played a critical, but as of yet unnoted, role in the propagation of banking panics during the Great Depression. At that time, three check-clearing systems operated in the United States. The Federal Reserve cleared checks for members of the system. Clearing houses cleared checks for banks belonging to their organizations. Correspondents cleared checks for all other financial institutions.

During November 1930, the failure of the Bank of Tennessee in Nashville, a principle 
correspondent for depository institutions in Tennessee and surrounding states, triggered a chainreaction. The ensuing collapse of its correspondent network forced more than one hundred banks to cease operations. Bank runs radiated from the locus of this counter-party cascade, forcing hundreds of additional banks to close their doors to depositors, and inducing most other banks in the affected regions to slow the conversion of deposits to currency through various mechanisms short of suspension. Several separate, smaller correspondent chains collapsed in the weeks that followed. Later surges in bank suspensions also disproportionately afflicted banks that cleared checks through correspondents.

A comparison of the three check-clearing systems reveals reasons why correspondent networks collapsed like dominos at the onset of the banking crisis. Large banks providing correspondent services resembled central banks. Deposits in correspondents counted as a portion, usually the preponderance, of a client bank's reserves. When a correspondent closed, these reserves disappeared, and the client bank had to suspend operations. If the client, in turn, had correspondents of its own, those banks had to suspend operations as well.

A ubiquitous feature of pre-depression correspondent-clearing networks exacerbated the situation. To facilitate book-keeping, country banks treated checks working their way through the correspondent-clearing system as entering their reserve accounts immediately upon deposit, or if the checks were deposited through the postal system, at the time the checks were handed to the postmaster. Correspondents provided immediate credit on all items deposited by country clients. Checks traveling through the correspondent clearing system usually traveled through the hands of at least two banks before being redeemed at the bank on which they were drawn. The reserves of banks using the correspondent-clearing system consisted, therefore, partially of checks in transit, and this float was magnified by a multiple depending upon time in transit and 
the number of banks through which checks passed.

Contemporary critics of the correspondent-clearing system called these reserves fictitious, since they consisted merely of book-keeping entries on the balance sheets of banks, and were not, in reality, backed by funds. Fictitious reserves peaked during the fall harvest season, when the flow of funds through correspondent networks to country banks and their agricultural clients peaked. Fictitious reserves also fluctuated with the behavior of bankers and the business cycle. Evidence indicates that the ratio of checks in transit relative to bankers' balances, a measure of the share of reserves which were fictitious, rose rapidly during the 1920s and peaked in fall of 1930, immediately preceding the onset of banking panics.

The remainder of this essay documents these hitherto unrecognized facts and describes how they contributed to the collapse of the banking system during the Great Depression. Section 1 describes the three check clearing systems that operated in the United States circa 1929. Section 2 describes the sources of evidence that reveal the connection between payment systems and bank distress. Section 3 illuminates the initial collapse of correspondent networks and their impact on banks in surrounding regions. Section 4 illustrates the fate of correspondent networks later during the depression. Section 5 discusses the implications of these findings. The collapse of correspondent networks played a hitherto unrecognized role in the banking crises of the 1930s.

\section{Section 1: The Three Check Clearing Systems}

Around the turn of the twentieth century, checks became the predominant method of payment in local and long-distance trade. In response to the vast volume of payment orders presented at financial institutions, bankers established systems for routing checks from banks in which they were deposited to banks on which they were drawn. Three such check clearing 
systems operated in the United States at the onset of the Great Depression.

The first system consisted of clearing houses. A clearing house was an association created by banks doing business in one locality to provide a uniform and convenient method of exchanging checks and settling balances on a daily basis. The association was governed by a constitution and a set of regulations adjudicated by an elected committee. Membership was voluntary. A bank joined a clearing house by depositing with the organization either cash or securities at a fixed ratio either to their capital stock or their deposits. In return, the bank received certificates issued by the organization and used to pay daily balances due to other banks belonging to the association. To settle accounts, representatives of each bank arrived at the clearing house each day at a designated hour, usually in the morning, presented items for collection at other banks, received claims against their own bank, checked to determine which items presented for collection would be rejected if presented at a teller's window (e.g. "not sufficient funds," "payment stopped," "improperly endorsed," etc.), ascertained the amounts due each bank, and finally, issued the appropriate certificates of debit and credit.

As clearing houses gained experience with their primary function of facilitating check transactions among members, their members realized that they could utilize the organizations to attain other goals. One common goal was the quick, safe, and inexpensive settlement of transactions with institutions outside the organization. All banks accepted for deposit checks drawn on banks beyond their town's limits. Rather than redeeming these items individually, via messengers or through the mail, which could be a time consuming and expensive process, particularly for items of low value, for which the cost of redemption could exceed the amount of remuneration, the clearing house gathered together all checks that members of the clearing house wished to clear from banks around the nation, and then processed and forwarded those checks 
collectively. The joint processing of checks economized on labor, postage, and exchange charges.

In the 1890s, the Boston Clearing House was the first organization to establish such a system for the 'collection of country items.' It eventually reduced the expense of redemption to a nominal amount, less than seven cents per thousand dollars. By 1913, almost all banks in New England participated in the Boston clearing system, enabling their checks to circulate freely throughout the region, and enabling them to settle outstanding balances with a single, daily remittance to the clearing house (Talbert 1913 pp. 204-206). Under the system, Boston banks received at par checks from all New England banks. The Boston clearing house received, recorded, and forwarded the items for collection to the institutions on which they were drawn. Members of the Boston Clearing House received at par credit for the items on the second day following their dispatch. The Kansas City Clearing House, which adopted such a system in 1905, cut the costs of collection in half within 5 years (Young 1910, see also Preston 1920 p. 568). The Detroit Clearing House had a similar experience (Preston 1920 p. 568). In 1912, the New York Clearing House, which had begun regulating collection terms on country checks in 1898, established a system for clearing checks from the states of New York, New Jersey, Massachusetts, Rhode Island, and Connecticut. In 1913, the bankers of St. Louis approved a similar plan.

Another common goal was maintaining depositors' confidence in the soundness of local banks. Bankers recognized that "no bank can be in an unsound position without hurt to the whole local banking community (Young 1910 p. 608)." To detect instances of unsound banking, to restore confidence during unwarranted runs on individual institutions, and to affect remedies quicker than possible by state or national officials, clearing houses established examination 
bureaus. These bureaus monitored the balance sheets of banks belonging to the organization, audited institutions periodically, and promptly checked into reports of irregularities. Threatening to expel weak banks from the organization enabled "the clearing house as a body to exercise such supervision of any weak bank as to amount to a virtual taking over of its management till it is again in sound condition (Young 1910 p. 608)."1

A third common goal was the provision of liquidity, particularly during periods of panic, when depositors withdrew funds en masse, forcing banks to scramble for cash. In such circumstances, clearing houses eased the pressure on bank balance sheets by issuing clearing house certificates. These substitutes for currency circulated between banks and among their better customers, usually bigger businesses, alleviating the pressure to sell assets at depressed prices (Talbert 1913 p. 195). Clearing house members also pooled resources and raised cash in large quantities by borrowing from banks in central reserve cities, or taking lines of credit from financiers or industrialists, or accessing equity markets. Clearing houses used these funds to aid banks undergoing runs and to convince depositors that they could meet all contingencies.

If all else failed, clearing houses coordinated temporary suspensions of payment, when all banks in a region ceased converting deposits into cash, until efforts to repair depositor's confidence yielded results, and banks were able to reopen. Coordinated closures ensured that no bank suffered lasting stigma relative to its competitors for suspending payments in times of trouble.

Clearing houses began operating in commercial centers in the United States during the

1 Note: Many clearing house examination bureaus also monitored borrowers within their communities, to detect duplications of borrowings by the same client at different banks, and to alleviate adverse selection among borrowers, by collecting detailed information on loan applicants, and disseminating it to all institutions, ensuring that borrowers could not refuse to provide information or security to an individual institution by threatening to borrow elsewhere. Young writes that "little has yet been said of the possibility of further development through such an office ... with regard to the question of credit information (Young 1910 pp. 130-131)." Scattered historical accounts appear to indicate that clearing houses expanded their operations along such lines during the 1910 s and 1920s, but I have found no solid body of data on the practice. 
second half of the nineteenth century. Banks in New York City organized a clearing house association in October 1853. On October 11, the first day of operation, total clearings amounted to $\$ 22,648,109.87$. The number of clearing houses grew rapidly during the second half of the century. By 1929, the year in which the Roaring 20s peaked and the stock market crashed, clearing houses operated in 349 municipalities in the United States. Each day, these associations cleared transactions totaling billions of dollars. At the New York Clearing House alone, daily clearings averaged $\$ 1,508,046,030.73$ (Andrews 1942 pp. 587-588).

Table 1 examines the distribution of clearing houses in the United States. In 1930, clearing houses operated in 45 of 48 states and the District of Columbia. Banks belonging to clearing houses numbered 2,186 . These banks comprised $57.5 \%$ of the 3,805 banks located in clearing house cities. In the central reserve city of Chicago, 142 of 240 banks belonged to the clearing house. In the central reserve city of New York, only 34 of 222 banks belonged to the clearing house.

Table 2 examines the distribution and characteristics of clearing houses with official examination bureaus. The preponderance of these bureaus existed in cities possessing a Federal Reserve district or branch bank. These cities were, of course, hubs of the financial industry. The banks within them often served as correspondents for country banks in the vicinity.

The second check clearing system consisted of correspondent banks. Correspondents were banks with ongoing relationships facilitated by deposits of funds. The typical situation involved a bank outside a reserve city (called a country bank) that deposited funds in a bank in a reserve city (called a city bank) and received services in return. The cornerstone of the relationship was the clearing of checks. When a country bank received out-of-town checks from depositors, rather than mailing the checks directly to the banks on which they were drawn, the 
country bank deposited the checks in its city correspondent. The correspondent cleared the checks through the most convenient method, either through a clearing house, through the Federal Reserve System, or by directly contacting the institution on which the checks were drawn. Country banks found the services of city correspondents economical, because a correspondent enabled them to clear checks by making a small number of daily deposits via the United States postal service, rather than employing a staff of clerks to handle the volume of correspondence needed to send each check directly to bank of origination. Correspondent clearing also enabled country banks to avoid exchange charges, the fee that many banks charged for remitting payment for checks drawn on them not cashed over the counter.

In addition to cashing checks, correspondents offered client banks an array of financial services. Correspondents supplied coins and currency, conducted wire transfers, facilitated investments in stocks and bonds, and offered investment advice. One of the most important services that correspondents offered was a line of credit. Correspondents routinely provided overdraft protection for their country clients and allowed clients to borrow against future flows of funds. Correspondents monitored the financial status of clients, enabling them to respond to clients' requests for credit more quickly than could any other institution. Correspondents provided clients with access to domestic exchange markets, where banks bought, borrowed, loaned, and sold excess reserves deposited at correspondent banks in reserve cities.

Domestic exchange markets existed in part because deposits with correspondents in reserve cities formed a portion of country banks' legal reserves. The National Banking Act established a system in which all country banks held reserves in banks in reserve cities, and all banks in reserve cities held reserves in banks in the central reserve cities, New York and Chicago. Table 1 indicates the interstate distribution of reserve cities and shows that in 1930, 
almost all reserve cities contained clearing houses. State regulations conformed to this nationwide pyramiding of reserves, although in some states, state-chartered banks could hold reserves in designated banks within their state as well as reserve cities in other jurisdictions.

On the eve of the Great Depression, correspondent networks formed a complex web of long-term interbank relationships anchored by banks in large commercial centers. A country bank often had a correspondent located in a nearby town, which was a member of the Federal Reserve, and therefore, could conveniently supply it with cash and clear many of its checks. A country bank also often possessed at least one correspondent in a financial center. The choice of correspondent depended on the needs of the respondent bank and its depositors. If the latter wished to invest in New York or international markets, than the country bank needed a New York correspondent who could handle those transactions. If the latter wished to invest in markets centered in Chicago, such as agricultural commodities, then the country bank needed a correspondent in Chicago. These incentives generated a system organized geographically. Regional financial centers, such as Boston, Cincinnati, Philadephia, San Francisco, and St. Louis, served banks in the surrounding states. St. Louis correspondents, for example, primarily served banks operating in Missouri and Arkansas. From these regional centers, interregional payments flowed primarily through New York banks.

Table 3 presents an example of a correspondent network extending outward from a unitbanking agricultural state, Mississippi, in the year 1929. Column (i) indicates that all banks in the state had at least one correspondent. The median, mean, and mode were three correspondents. The maximum was five. The most common set-up for an individual bank was to have one correspondent in the city containing the Federal Reserve Bank of their district (i.e. Atlanta for banks located in southern Mississippi, which lay in the $6^{\text {th }}$ District; and St. Louis for banks 
located in northern Mississippi, which lay in the $8^{\text {th }}$ District); one correspondent in a central reserve city, usually New York; and one correspondent in a commercial center outside of the state, often New Orleans.

The correspondent banking system evolved during the nineteenth century. As early as 1830, rural banks deposited reserve balances in metropolitan banks to facilitate the redemption of bank notes. In return for maintaining a minimum reserve deposit, metropolitan correspondents agreed to redeem their cumulative notes at par or a fixed discount (James and Weiman 2004 p. 13). As banks evolved from suppliers of cash to deposit money, and as transactions shifted from currency to drafts to checks, the correspondent system kept pace. Checks drawn on a local bank's correspondent account in New York or similar financial center became the most common medium for settling debts across communities. Providing correspondent services became the principal activity of the largest banks in national financial centers of New York and Chicago, where more than half of all deposits consisted of bankers' balances, and was an increasingly important segment of the market in regional financial centers. Correspondent banks grew increasingly profitable, as correspondents used connections to client banks to market an ever growing array of financial services and as a basis for building branch, group, and chain banking systems.

Correspondent banking expanded during the decades before the Great Depression, because the correspondent system had strengths relative to potential alternatives. The centralization of clearing and settlement services among money center banks yielded scale economies that reduced transaction costs and information externalities that reduced the risk of check transactions (James and Weiman 2004). The concentration of reserves in money center banks enabled the banking system as a whole to economize on reserve holdings, since banks 
could participate in an interbank domestic exchange market, where institutions bought or borrowed surplus correspondent balances, and thus, could buffer against transitory and seasonal flows of funds. This liquidity externality "diminished the volatility of domestic exchange rates in regional markets and lower[ed the] volatility of bankers' balances in larger reserve cities," making the banking system as a whole more stable and profitable (James and Weiman 2004 p. $5)$.

The correspondent banking system, however, also had weaknesses. ${ }^{2}$ The first was a standard practice of all major correspondent banks. Clients could immediately count checks deposited as a portion of their reserves. The correspondent bank itself carried "the float."

It has long been recognized that the chief defense of the plan was its convenience. A country bank in this way knew how its reserve account stood. No checks were charged until the country bank remitted, and checks sent to the city correspondent were counted as available reserve as soon as put into the mail. In this way a fictitious reserve was created. A check in the mail for several days might later be returned for want of funds. All of this time the various banks that had handled it would count as reserve these unavailable funds (Preston 1920 p. 567).

Regulatory authorities in all states approved of this long-standing practice, since its convenience seemed to offset potential disadvantages, such as allowing customers to write checks against uncollected funds. Moreover, "rural states adopted liberal bank incorporation laws that reduced minimum capital requirements to a fraction of the federal threshold and so spurred the formation of state-chartered banks in smaller cities and towns (James and Weiman 2004 p. 8).”

These state regulations and common practices created a connection between correspondent clearing and bank reserves with perilous potential. Bank reserves in the correspondent system were inflated by a multiple of the volume of checks in transit. Each check

\footnotetext{
${ }^{2}$ Advocates of Federal Reserve check clearing often criticized two additional features of the correspondent clearing system: first, the practice of exchange charges, which were fees charged for redeeming checks; and second, circuitous routing of checks, in order to avoid exchange charges. I do not focus on those problems, since they are orthogonal to the issues of this essay, and because the Federal Reserves' drive to expand par territory alleviated these problems by the late 1920 s.
} 
in transit counted was counted as part of the reserve of every bank through which it passed, until the check was redeemed, and the funds flowed backwards through the system, and the pyramiding unwound. Consider, for example, the case of a check sent by a textile factory in New England drawn on a Lowell bank with a Boston correspondent to a cotton-farmer in Alabama who deposited the check in his local bank with a Birmingham correspondent which routed the check through its New York correspondent on the way back to New England. At its peak, the value of the check would be added to the reserve account of the four banks through which it traveled: the local Alabama bank, its Birmingham correspondent, its New York correspondent, and the Boston correspondent. Meanwhile, the funds needed to pay the check remained within the merchants account at the Lowell Bank which counted those funds as part of its reserve. If all correspondent chains were this length, the total quantity of fictitious reserves in the correspondent system would be the value of all checks in transit multiplied by $4 .^{3}$

Seasonal flows of funds from crop-growing regions exacerbated the situation. Agricultural states possessed large numbers of small rural banks that relied on correspondents to clear checks. Business for these banks peaked during the harvest and planting seasons, when farm lending, flows of crops, and flows of funds from cities to the hinterland peaked. During these periods, it would not be unusual for an institution in a small town to process checks equal to its required reserves within each week. If those checks took a week to clear through correspondents (also a typical period), then the bank's possessed no actual reserves, since the

\footnotetext{
${ }^{3}$ No source provides a figure or basis for determining this multiplier. It must have been at least one. Here, I provide a rough estimate. If the volume of checks in transit was constant, if all banks sent checks through the system via the most direct route to a correspondent which belonged either to the New York Clearing House or the Federal Reserve System, if all correspondents routed their checks through either the New York Clearing House or the Federal Reserve System, if the Mississippi correspondent network was representative of correspondent networks throughout the nation, and if funds returned at the same rate that checks moved through the system, then the multiplier would have been approximately 1.5 . In other words, the aggregate funds actually available as reserves to correspondent banks, denoted A, would have been the $\mathrm{A}=\mathrm{B}-(1.5) * \mathrm{~F}$, where $\mathrm{B}$ was the amount of reserves that banks carried on their books and $\mathrm{F}$ was the float.
} 
'float' (a.k.a. fictitious reserves) exceeded the 'reserves' that they carried on their books.

The growing number of banking chains and groups may have exacerbated the situation. A chain was a collection of independently chartered banks controlled by an individual or organization, usually through stock ownership or interlocking directorates. A group was a collection of independently chartered banks operating under the auspices of a corporate conglomerate. Each bank in the group had its own board of directors, but the holding company coordinated the activities of all the banks in the group and owned a majority of the capital stock in member banks. In chains and groups, the leading bank usually served as a correspondent for the other institutions, an arrangement which allowed chains and groups to economize on reserves and diversify risk across a diverse pool of assets. The presumed advantages of this arrangement may have been squandered by accounting conventions that overstated the reserves of the organization as a whole. These conventions obscured the true state of chains' and groups' financial health, confused management, and distorted incentives. In certain cases, according to contemporary accounts, these distortions induced management to artificially expand reserves by reciprocal clearing of checks, slowing the processing of checks in transit, and other arrangements that increased float, and thus reserves, without affecting real financial resources.

For these reasons, the connection between clearing and reserves placed the correspondent system in a perilous position. A large portion of the reserves of the correspondent system consisted of 'fictitious' reserves equal to a multiple of the volume of checks in transit. The reserves of the correspondent system appeared to expand (but in reality did not change) whenever the volume of checks in transit or the length of correspondent chains (and thus the number of banks through which a check passed) increased. Any disruption of the clearing system that prevented the payment of checks forced the revelation of the fictitious reserves. An event, 
such as a banking panic, that forced banks to convert reserves into cash, would reveal that the much of the reserves in any correspondent chain consisted of fictitious figures based on the multiplication of the value of checks in transit.

Precise data on the quantity of fictitious reserves does not exist, but extant sources yield closely related statistics. One is the ratio of checks in transit to bankers' balances for state commercial banks. This is a lower bound for the share of reserves which were fictitious. ${ }^{4}$ Figure 1 displays the data for July 1 of each year from 1913 to 1940 . The ratio peaked in 1930, when float approached $60 \%$ of bankers' balances. This percentage was nearly twice the proportion prevailing during the preceding decade. The percentage was more than four times the proportion prevailing following the trough of the contraction.

In 1913, in order to alleviate the problem of fictitious reserves, lower the costs of clearing checks, increase the efficiency of the payments system, and facilitate industry and commerce, Congress required "every federal reserve bank to receive on deposit, at par and without charge for exchange or collection, checks and drafts drawn upon any of its depositors (Federal Reserve Act 1913)." Congress authorized the Federal Reserve Board to make "regulations governing the transfer of funds at par among federal reserve banks, and authorized the Federal Reserve System to "exercise the functions of a clearing house for Federal Reserve member banks (Federal Reserve Act 1913).” In July 1916, the Federal Reserve's system of check clearing initiated operations. Over the next five years, operations expanded rapidly, as the Federal Reserve modified services to make them more efficient, and legal changes required Fed member banks to clear their checks as directed by their Federal Reserve district.

4 The ratio which we measure is a lower bound because it includes figures from all state commercial banks, including members of the Federal Reserve System and members of clearing houses. Federal Reserve members cleared checks through the system, and thus, had much lower levels of checks in transit than non-member state banks. Clearing house banks, particularly in major money centers, also cleared checks more rapidly and credited them more slowly than banks that cleared via correspondents. 
By the 1920s, the Federal Reserve's check clearing system had matured. The Fed cleared checks both within and across districts. Each day, Federal Reserve members submitted the checks that they received to the nearest Federal Reserve office. The Fed office routed the checks directly to banks within its district and to the pertinent Federal Reserve district office for banks belonging to other districts. The Federal Reserve also accepted checks from non-member banks on the par list, which included about $90 \%$ of the banks in the nation. Banks on the par list paid at face value checks sent to them by the Federal Reserve. Most did so voluntarily, and in exchange, the Federal Reserve covered the costs of their efforts by supplying the necessary forms and preprinted and pre-posted envelopes. A few did so reluctantly, after the Federal Reserve hired local agents to redeem checks at the bank's teller's window, where the law required them to redeem checks at par.

In cities with clearing houses, the pre-Federal-Reserve arrangements for clearing checks remained, albeit in a modified form. The clearing houses provided the machinery and experience necessary for handling tremendous volumes of transactions. The Federal Reserve decided, therefore, that it would not handle checks between banks located in the same clearing-house city, and it informed banks of this decision at the inauguration of its plan.

In cities possessing both a clearing house and Federal Reserve branch, settlements of clearing house balances were made by debiting or crediting accounts on the books of the Federal Reserve branch, in which all members of the clearing house were required to keep deposits, even those that did not belong to the Federal Reserve System. In March 1917, New York adopted this system, and it spread swiftly to most cities boasting both clearing houses and Federal Reserve branches (Andres 1942 p. 595). During the 1920s, clearing houses in cities outside of Federal Reserve cities also began to adopt the practice of settling balances by transfers on the books of 
the Federal Reserve, by simply requiring clearing house members to open accounts at the Federal Reserve and telephoning or telegraphing the debits and credits to the Federal Reserve at the end of each business day (Andrews 1942 p. 596).

In many cities possessing both clearing houses and Federal Reserve branches, closer cooperation evolved. Federal Reserve branches had a reason to belong to the local clearing house, since a Fed branch received numerous checks drawn on banks in its city, and the clearing house was the most convenient method of clearing them. Most clearing house associations admitted their local Federal Reserve branch, under special arrangements.

"Customarily, the reserve bank has no vote or voice in the management of the association, is not subject to the examinations or reports often prescribed for the association members, and need not sign the constitution or articles of the association. Usually the [Federal Reserve] bank must help to bear the expenses of the association ... [since] the reserve bank enjoys the clearing privilege, it is required to abide by the clearing rules, including such matters as time for exchanging items, form in which items are to be brought to the exchanges, time and manner of returns, and the like (Andrews 1942 pp. 606-607)."

In some cities, the Federal Reserve took over the operation of the clearing house. For example since July 15, 1916, the Federal Reserve Bank of Boston furnished the equipment and paid the salaries of the clerks for the Boston Clearing House Association (Andrews 1942 p. 606).

The Federal Reserve cleared all other checks in a manner resembling the procedures employed by correspondent banks. The Federal Reserve shipped batches of checks to banks on which they were drawn, either via private messenger or the postal services, and awaited the return of funds (usually in the form of a draft drawn on an account of a Federal Reserve member or a money center bank) via the same means. The Federal Reserve and correspondent systems differed, however, in a crucial aspect. The Federal Reserve did not immediately credit out-of-town checks to the accounts of banks 
that deposited them. The Fed imposed a waiting period whose length was based on the typical length of time that it took for a check drawn on a type of bank in a particular location to remit funds.

The waiting periods varied up to eight business days depending on the distance involved and the type of bank on which the draft was drawn. The schedule of the Federal Reserve Bank of New York was the most expeditious. New York provided immediate credit for drafts deposited before 9 am and payable at New York City Clearing House Association Banks, Northern New Jersey Association Clearing House Banks, or certain other New York and Brooklyn banks. It also provided immediate credit for drafts drawn on its own members and certain warrants and obligations of the United States Treasury and the Federal Reserve System. It credited checks drawn on banks in east coast cities within one or two days, south eastern cities within three days, mid-western cities within four days, and San Francisco and Los Angeles within five days. Credit for items over $\$ 500$ was delayed one day. The longest waiting period, of seven business days, pertained to drafts drawn on banks in western and Pacific states that belonged neither to a clearing house nor the Federal Reserve System. ${ }^{5}$

\section{Section 2: Sources of Data}

The previous section describes the payment systems operating on the eve of the Great Depression. The descriptions is based on the professional and academic literature of the era, information available in bankers' handbooks and manuals, and contemporary sources widely available at the time and often employed by economists pondering the causes and consequences of the depression. Data on clearing houses, reserve cities, reserve requirements, and

5 See Rand McNally Bankers' Directory for a complete recapitulation of each Federal Reserve banks' time schedule for crediting deposits. 
correspondent linkages comes, for example, from Rand McNally's Bankers Directory.

The remainder of this essay is based on a new and unique source. During the 1920s, the Federal Reserve Board of Governors developed a lexicon for discussing bank suspensions and procedures for collecting data on the phenomenon. They preserved their conclusions on the St. 6386 series of forms. This section concisely characterizes the terms that the Federal Reserve devised to describe the causes of banks suspensions. Richardson (2005) delves into details of the definitions and the data collection process.

In the Federal Reserve's lexicon, a suspension was a bank that closed its doors to depositors and ceased conducting normal banking business for at least one business day. Some, but not all, suspended banks reopened for business. A liquidation was a permanent suspension. A liquidating bank closed its doors to the public, surrendered its charter, and repaid depositors, usually under the auspices of a court appointed officer known as a receiver. A voluntary liquidation was a category of closure in which banks ceased operations and rapidly arranged to repay depositors the full value of their deposits. Voluntary liquidations did not require the services of receivers and were not classified as suspensions. A consolidation (or merger) was the corporate union of two or more banks into one bank which continued operations as a single business entity and under a single charter. The categories of bank distress were typically construed to be temporary suspensions, terminal suspensions (i.e. liquidations), voluntary liquidations, and consolidations due to financial difficulties. ${ }^{6}$

The Federal Reserve attributed most bank suspensions to one of five common causes. The first was slow, doubtful, or worthless paper. The term worthless paper indicated an asset with little or no value. The term doubtful paper meant an asset unlikely to yield book value. The

6 Contemporary publications often employed the terms failure and closure as synonyms, which typically (but not universally) referred to the sum of temporary and terminal suspensions. 
term slow paper meant an asset likely to yield full value in time, but whose repayment lagged or which could not be converted to full cash value at short notice. The second common cause of suspension was heavy withdrawals, the typical example being a bank run. The third was failure a banking correspondent. Correspondents were banks with ongoing relationships facilitated by deposits of funds. A typical example is a county bank (the client) which kept its reserve deposits within and cleared its checks through a national bank in a reserve city (the correspondent). The fourth common cause was mismanagement. The fifth was defalcation, a monetary deficiency in the accounts of a bank due to fraud or breach of trust.

Table 4 summarizes the data by presenting numbers of banks failing for different reasons during each year. In the table, row (a) indicates the total number of banks suspending operations due to problems with assets and liabilities. Imbalances often arose on one side of the balance sheet, but could arise simultaneously on both sides. Rows (a.1) through (a.5) display the possible combinations: (a.1) slow, doubtful, or worthless assets listed as the primary cause of suspension; (a.2) assets listed as the primary cause and heavy withdrawals listed as a contributing cause; (a.3) both withdrawals and assets listed as primary causes; (a.4) heavy withdrawals listed as the primary cause and assets as the contributing cause; and (a.5) withdrawals alone as the primary cause of suspension. Row (b) indicates the number of banks suspending due to the closure of a correspondent. Row (c) indicates the number of banks suspending due to defalcations, mismanagement, excessive loans to officers and directors, excessive investment in building and facilities, and similar circumstances. Row (d) indicates the number of banks suspending due to other or multiple causes. The latter consists in part of complex cases which do not fit into the mutually exclusive categories above, often because they spanned two or more classifications. An example is a poorly managed bank which failed to enforce collections on its slow farm loans and 
which experienced runs after local newspapers revealed that its president embezzled funds from savings accounts

In Table 4, several patterns appear prominent. The share of suspensions due primarily to problems on the asset side of the balance sheet fell through 1931, rose in 1932, and fell again in 1933. The share of suspensions due primarily to withdrawals rose through 1931, fell in 1932, and rose again in 1933. The ratio of assets over withdrawals varied over time. Withdrawals' role in the collapse of the banking system peaked in 1931, while before and after, asset problems caused the majority of suspensions. The share of suspensions due to defalcation and mismanagement fell throughout the depression, perhaps because corrupt and poorly-managed institutions lacked the resources needed to weather the initial states of the storm. The share of suspensions due to the closure of correspondents peaked during 1930.

Figure 2 examines the data from a different perspective. It indicates the share of suspensions due to correspondents, withdrawals, and assets for the depression as a whole. The left-hand pie chart presents data for banks which suspended operations temporarily. The righthand pie chart presents data for banks which suspended operations permanently. The shades of gray indicate the percentage of banks suspending for different reasons. The color black denotes banks which suspended solely due to heavy withdrawals (in key, WITHDRAWALS) but which were in fine financial shape before depositors' demanded repayment of deposits. Most of these banks experienced sudden and severe runs. Three-quarters gray denotes banks forced out of operations by heavy withdrawals and also afflicted by asset troubles that exacerbated their condition, but which were not severe enough to have necessitated suspension in the absence of withdrawals (WITHDRAWAL + assets). One-half gray indicates banks in double trouble. Problems severe enough to necessitate suspension existed on both sides of the balance sheet 
(WITHDRAWALS \& ASSETS). One-quarter gray indicates banks whose slow, doubtful, and worthless assets forced them to close their doors and where withdrawals exacerbated the situation. Examples include (i) banks forced by continuous, slow withdrawals to sell their profitable assets leaving them with a problematic portfolio, and (ii) banks headed towards failure whose demise was accelerated by depositors' demands (ASSETS + withdrawals). Lightly-dotted gray indicates banks forced to suspend solely due to problematic assets (ASSETS).

Figure 2 demonstrates that for the contraction as a whole, asset problems were the primary cause of about half of all bank liquidations (i.e. terminal suspensions) and a contributing cause of another one-quarter. About five in ten of the banks which went out of business, in other words, had asset problems severe enough to have caused their demise. For temporary suspensions, the pattern was different. Temporary suspensions appear to have been issues of illiquidity. Banks suspended operations temporarily when they lacked enough cash on hand to satisfy the demands of depositors. Heavy withdrawals were the primary cause of more than a half of all temporary suspensions. The closure of counterparties caused a sixth of all temporary suspensions.

\section{Section 3: Correspondent Networks and the Initial Panic of the Depression}

The correlation between suspensions and the closure of correspondents was particularly pronounced during the initial banking panic of the depression. Figure 3 plots the number of suspensions each week due to the closure of correspondents (and for sake of comparison also plots total changes due to financial distress). The typical week witnessed few, if any, suspensions from this source. The weekly mode and median were zero. The weekly number rose during July of 1929, when a Mediterranean fruit fly epidemic produced a banking panic in Florida, and the suspension of banks in Tampa, which served as the principal correspondents for banks in central 
Florida, forced the banks to suspend operations throughout the region, but remained near zero until November 1930, when it spiked sharply upwards.

In a two week period, more than 120 banks were forced to suspend operations due to the closure of their correspondents. The event is an obvious outlier. Never before or since have so many financial institutions fallen in a counterparty cascade. It does not seem surprising that this event, the worst chain reaction in United States financial history, marked the onset of the worst period of bank distress and most catastrophic financial contraction in United States financial history. In the immediate aftermath, bank runs radiated from the locus of the counterparty cascade, forcing hundreds of banks to close their doors to depositors.

Figure 4 examines the event in more detail. Figure 4 uses the shading scheme of Figure 2 to portray the cause of suspensions during the fall of 1930 and winter of 1931, a period which witnessed the initial surge of bank suspensions during the Great Depression. Before midOctober, the pattern of bank suspensions resembled the pattern of failures throughout the 1920s. Banks failed at a steady rate. The principal cause was problems with asset quality. The pattern changed dramatically in November 1930, when the rate of suspension rose suddenly. The closure of correspondents caused the initial increase. Thereafter, runs (or fear of runs) forced scores of banks to close their doors, and adverse circumstances pushed many weak banks into insolvency. Comments written on the St. 6386 forms tell the tale. ${ }^{7}$ On November 7, the Bank of Tennessee (Nashville, TN) closed due to "depreciation in the value of securities" and irregularities which left it with "bills payable of $\$ 2,887,100.00$ " and debts "on real estate of

\footnotetext{
The archival evidence attributes the suspension of the principal banks controlled by Caldwell conglomerate to either: (a) financial difficulties directly attributed to Caldwell's demise, or (b) runs because of the banks known connection to Caldwell and Company. The archival evidence attributes the suspension of nearly 100 additional banks to: (a) the severing of correspondent links to institutions, such as the Bank of Tennessee, controlled by the Caldwell conglomerate, (b) runs due to known affiliations with the Caldwell organization, or (3) runs due to geographic proximity to Caldwell controlled institutions or geographic proximity to banks undergoing runs.
} 
$\$ 260,079.20$ " on a deposit base of $\$ 10,000,000 .^{8}$ In the following week, heavy withdrawals forced many banks in the city to suspend operations. On November 12, the Holston-Union National Bank (Knoxville, TN) closed due to heavy withdrawals "due to loss of confidence caused by failure of banks in Nashville" and the frozen state of its assets.

On November 17, armageddon arrived. The National Bank of Kentucky (Louisville, KY) suspended operations because of "heavy withdrawals and affiliation with the Caldwell Chain." The closure forced its affiliate, the Louisville Trust Company, to suspend operations on the same day. During the next week, eleven clients of the national bank suspended operations, as did four clients of the trust company. An additional client closed its doors soon thereafter. The Federal Reserve attributed the suspension of all of those clients to the severance of the correspondentclient linkage.

The American Exchange Trust Company (Little Rock, Arkansas) also suspended operations due to "heavy withdrawals due to rumors caused by failure of Caldwell and Company [in] Nashville.” The American Exchange Trust Company was the lead bank in the A. B. Banks chain and one of the principal correspondent institutions in Arkansas and the surrounding states. Its suspension forced 37 of its clients to suspend operations immediately. Another five suspended operations during the following week. Some of those clients - notably the Arkansas Trust Company (Newport, AR) and the Merchants and Planters Bank and Trust (Pine Bluff, AR) - had clients of their own, which suspended operations in turn.

One client of the American Exchange Trust Company remained in operation for a month. The Citizens Bank and Trust Company (Harrison, AR) endured by calling on the resources of the A. T. Hudsputh Chain, for which it was the principal bank. But on December 17, when those

8 This quotation contains all of the information necessary to locate the cited text in the central subject file of the Board of Governors in the National Archives. The appendix describes how to locate the original sources. 
resources ran thin and the loss of funds on deposit in the American Exchange Trust Company appeared irreversible, the Citizens Bank threw in the towel. Within 24 hours, its suspension caused seven of its client banks and the remaining members of the A. T. Hudsputh chain to suspend operations.

Similar events occurred in Illinois, where correspondent chains without connection to Caldwell collapsed. On November 8, Quincy-Ricker National Bank and Trust Company (Quincy, IL) suspended operations due to the collapse its largest borrower, the "Smith and Ricker Land and Cattle Company, of Kansas City, Missouri.” Its suspension soon forced four of its client banks to close their doors. During the following week, deposits fell steadily at banks in the vicinity. On November 14, cash reserves of the State, Savings, Loan, and Trust Company (Quincy, IL) ran out. It suspended operations. In the next three days, six of its client banks also closed. Three more did so during the next month. The effects of these suspensions spread across state lines. On November 20, the Hannibal Trust Company (Hannibal, MO) suspended operations due to "heavy withdrawals due to closing of a number of banks in their section at Quincy, Illinois.” The closing of the Hannibal Trust Company forced one of its clients, the Farmers Bank (Oakwood, MO), to suspend operations later that afternoon.

Similar dominoes of collapsing correspondent networks radiated out from Sioux City, Iowa and Clarksdale and Tupelo, Mississippi during December, 1930. On December 6, both the Sioux City National Bank and the First National Bank in Sioux City suspended operations due to “slow, doubtful, or worthless paper." Two days later, the Leeds Bank of Sioux City, a client of the former, closed its doors. On December 12, the Exchange Bank of Marcus, a client of the latter, ceased operations. On December 17, another client of the latter, The Alvord Bank (Alvord, IA) suspended operations. This was one of the four banks in the Charles Shade chain. The 
remaining banks of the chain (located in Inkwood, Larchwood, and Rock Rapids, IA) suspended operations at the same time. On December 24, the Peoples Bank and Trust Company (Tupelo, MS) suspended operations due to "excessive bills payable" and "slow, doubtful, and worthless assets." Its branches at Nettleton and Rienzi closed concurrently. During the next 24 hours, its suspension forced six state banks for which it served as correspondent, located in the towns of Fulton, Guntown, Saltillo, Shannon, Sherman, and Verona, to suspend operations. On December 1930, the Planters National Bank in Clarksdale suspended operations, forcing two of its clients into suspension and inducing banks in neighboring towns to suspended operations for fear of runs.

\section{Section 4: Correspondent-Clearing and Bank Closures during 1931 and 1932}

The previous section showed that the collapse of correspondent-clearing networks triggered the initial banking crisis in the fall of 1930. This section shows correspondent clearing networks played a role in later local and regional panics. An example is the surge in bank suspensions in Illinois in the spring of 1931, an event that Friedman and Schwartz (1963) named the Second Banking Crisis. The Federal Reserve attributed only three suspensions in this panic directly to closures of correspondents. One of the suspensions was in Florida, one in Nebraska, and one in North Carolina, all far from the locus of suspensions in Illinois.

Yet, Federal Reserve agents indicated that of the 25 banks which suspended in Chicago between June $6^{\text {th }}$ and $10^{\text {th }}$, eleven belonged to the John Bain Group, seven belonged to the Foreman Group, and one belonged to the Ralph E. Ballou and E. L. Wagner Group. For almost all of those suspensions, the Federal Reserve determined heavy withdrawals to have been the primary cause and slow or frozen assets to have been a contributing cause. The same was true of almost all other suspensions in Illinois and adjacent states. Federal Reserve agents stated 
laconically on most of the forms that the bank closed its doors after depleting its cash reserves. These comments suggest an epidemic of illiquidity plagued these banks. Depositors wanted cash. The banks' assets were frozen. The banks closed because they could not meet depositors' demands.

Each of these banking groups was a collection of independently chartered institutions operating under the auspices of a corporate conglomerate, which owned a majority of the capital stock in each of the banks, and by appointing directors and hiring managers, controlled their affairs. The leading bank of each of these groups served as the correspondent for the subordinate institutions. The groups were relatively recent innovations. They had grown during the preceding decade, as correspondent banks in Chicago expanded their businesses by absorbing responding institutions.

Table 5 examines the relationship between clearing systems and bank closure for the contraction as a whole. The table indicates the number of banks that suspended operations temporarily and terminally in three groups: first, banks that cleared checks solely through correspondents; second, banks that belonged to clearing houses (but not the Federal Reserve System); and third, banks that belonged to the Federal Reserve System (including those that also belonged to clearing houses). The table shows that the preponderance of banks that suspended operations cleared checks via correspondents. About a fifth belonged to the Federal Reserve System. Only a small fraction belonged to clearing houses.

Across these groups, the percentage of banks that suspended operations temporarily or terminally varied. Over one-third of all banks that cleared checks via correspondents suspended operations at some point during the depression, and over one-fourth permanently ceased operations before the banking holidays began in March 1933. These rates were four times higher 
than those of clearing-house members and two-and-one half times larger than those of Federal Reserve members. The failure of the later two types was concentrated during the three months following Britain's abandonment of the gold standard in the fall of 1931, to which the Federal Reserve reacted by contracting the money supply and raising interest rates. That reaction changed fundamentals in a way which burdened money center banks. So did later periods of contractionary policy. Outside of those periods, banks that cleared checks via correspondents failed at rates much higher than banks which cleared checks through clearing houses or the Federal Reserve.

These raw correlations do not, of course, reveal why banks that cleared via correspondents failed at such high rates. Banks that cleared via correspondents differed from clearing-house and Fed-member banks along many dimensions, such as location, size, investment opportunities, customer base, regulatory environment, access to the discount window, and management expertise. Those dimensions undoubtedly influenced banks' prospects for success (or failure). Determining which was the most important requires the collection of additional data and the development of techniques to separate the effects of check-clearing contagion from other factors.

\section{Section 5: Conclusion}

The correspondent check clearing system played a hitherto unrecognized role in the collapse of the banking system during the contraction of the early 1930s. The initial banking crisis began when a correspondent system in the center of the United States imploded, causing the closure of more than one hundred institutions. Panic radiated from the locus of events, as bank runs spread throughout the Mississippi, Missouri, and Ohio River watersheds, and additional correspondent networks succumbed to the situation. The second banking crisis began 
when depositors simultaneously withdrew large sums from several banking groups in northern Illinois. These banking groups were correspondent networks whose leading institutions had gradually taken control of their client banks during the 1920s. For the entire contraction, banks that relied upon correspondents to clear checks failed at much higher rates than banks which cleared via clearing houses or the Federal Reserve.

Correspondent networks were always vulnerable to counter-party cascades. The institutions formed a line like dominoes. One bank held deposits for another bank, which in turn, held deposits for a third. These deposits comprised the preponderance of the dominoes' reserves (both required and excess). When one domino toppled, the reserves of the next domino disappeared, and it suspended operations also, which forced additional dominoes to fall.

Accounting conventions employed by correspondent banks exacerbated the situation. Banks that cleared via correspondents counted checks in transit as part of their reserves. This convention exaggerated on paper the resources available to individual institutions and the system as a whole in reality. Banks' balance sheets indicated that they possessed abundant reserves, when in reality, they possessed few, if any, resources. The summer and fall of 1930 witnessed the historical peak in the accumulation of these fictitious reserves. The panics that began in October of that year forced the revelation of banks' reserve positions. Simultaneous revelation revealed the cancer lurking within the correspondent system. In such circumstances, it is no wonder that the system collapsed so suddenly and so extensively.

Banks that belonged to the Federal Reserve System and clearing houses did not suffer such circumstances. The Federal Reserve processed drafts quicker and credited accounts slower than did correspondent banks. Their clients did not accumulate fictitious reserves. Their accounting conventions did not conceal the true state of their client's (and their own) reserve 
positions. This difference is likely to be one reason that Federal Reserve and clearing house members faired better than other banks during the initial years of the contraction. 
Table 1

Clearing Houses, Federal Reserve Facilities, and Reserve Cities by State, 1930

\begin{tabular}{|c|c|c|c|c|c|c|c|c|c|c|c|c|c|c|c|}
\hline & 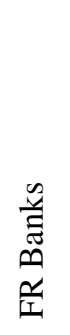 & 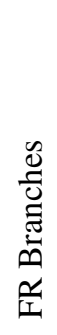 & 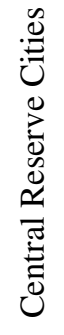 & 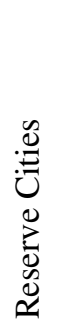 & 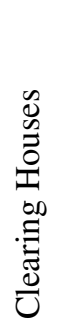 & 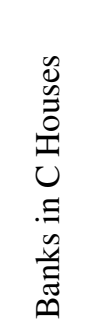 & 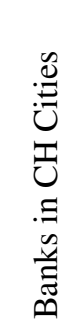 & & $\begin{array}{l}\tilde{n} \\
\tilde{\Xi} \\
\tilde{D} \\
\underline{\underline{I}}\end{array}$ & 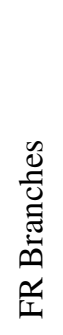 & 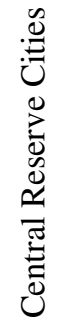 & 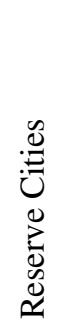 & 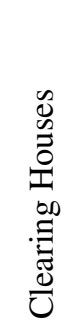 & 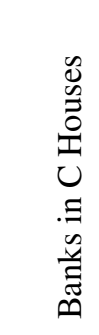 & 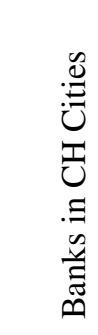 \\
\hline & (1) & (2) & (3) & (4) & (5) & (6) & (7) & & (1) & (2) & (3) & (4) & (5) & (6) & (7) \\
\hline Alabama & & 1 & & 1 & 4 & 17 & 37 & New Hampshire & & & & & 1 & 4 & 13 \\
\hline Arizona & & & & & 2 & 9 & 12 & New Jersey & & & & & 8 & 66 & 100 \\
\hline Arkansas & & 1 & & 1 & 3 & 16 & 21 & New York & 1 & 1 & 1 & 1 & 11 & 85 & 328 \\
\hline California & 1 & 1 & & 3 & 24 & 111 & 202 & North Carolina & & 1 & & 1 & 9 & 35 & 46 \\
\hline Colorado & & 1 & & 2 & 3 & 22 & 31 & North Dakota & & & & & 5 & 15 & 21 \\
\hline Connecticut & & & & & 1 & 30 & 61 & Ohio & 1 & 1 & & 4 & 17 & 107 & 168 \\
\hline Delaware & & & & & 1 & 8 & 16 & Oklahoma & & 1 & & 2 & 7 & 29 & 50 \\
\hline Florida & & 1 & & 1 & 7 & 28 & 63 & Oregon & & 1 & & 1 & 3 & 16 & 39 \\
\hline Georgia & 1 & & & 2 & 13 & 41 & 75 & Pennsylvania & 1 & 1 & & 2 & 34 & 243 & 419 \\
\hline Idaho & & & & & 3 & 6 & 9 & Rhode Island & & & & & 1 & 9 & 16 \\
\hline Illinois & 1 & & 1 & 1 & 15 & 214 & 321 & South Carolina & & & & & 9 & 32 & 47 \\
\hline Indiana & & & & 1 & 14 & 92 & 165 & South Dakota & & & & & 4 & 13 & 19 \\
\hline Iowa & & & & 4 & 13 & 71 & 97 & Tennessee & & 2 & & 2 & 5 & 30 & 58 \\
\hline Kansas & & & & 3 & 11 & 91 & 106 & Texas & 1 & 3 & & 7 & 16 & 81 & 130 \\
\hline Kentucky & & 1 & & 1 & 5 & 27 & 48 & Utah & & 1 & & 2 & 3 & 15 & 24 \\
\hline Louisiana & & 1 & & 1 & 1 & 9 & 13 & Virginia & 1 & & & 1 & 5 & 27 & 53 \\
\hline Maine & & & & & 2 & 12 & 15 & Washington, D.C. & & & & 1 & 1 & 37 & 44 \\
\hline Maryland & & & & & 3 & 30 & 64 & Washington & & 2 & & & 6 & 26 & 80 \\
\hline Massachusetts & 1 & & & 1 & 8 & 56 & 134 & West Virginia & & & & & 2 & 18 & 23 \\
\hline Michigan & & 1 & & 2 & 12 & 56 & 111 & Wisconsin & & & & 1 & 11 & 96 & 117 \\
\hline Minnesota & 1 & & & 2 & 11 & 89 & 123 & Wyoming & & & & & 2 & 5 & 6 \\
\hline Mississippi & & & & & 7 & 19 & 27 & & & & & & & & \\
\hline Missouri & 2 & & & 3 & 12 & 106 & 185 & & & & & & & & \\
\hline Montana & & 1 & & 1 & 3 & 11 & 12 & & & & & & & & \\
\hline Nebraska & & 1 & & 2 & 6 & 26 & 56 & United States & 12 & 24 & 2 & 57 & 349 & 2,186 & 3,805 \\
\hline
\end{tabular}

Source: Rand McNally Bankers’ Directory, July 1930

Notes: Column (1) indicates the number of Federal Reserve District Banks in the state. Column (2) indicates the number of Federal Reserve Branch Banks. Column (5) indicates the number of cities with clearing houses. Column (6) indicates the number of banks belonging to clearing houses. Column (7) indicates the number of banks located in cities containing clearing houses. 
Table 2

Clearing Houses with Examination Bureaus

By Region and City Characteristics, 1930

\begin{tabular}{|c|c|c|c|c|c|c|c|c|c|}
\hline City & State & 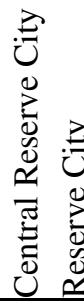 & & 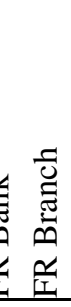 & City & State & 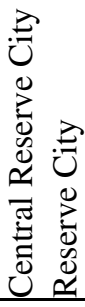 & صै & 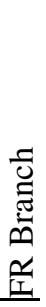 \\
\hline New England & & & & & $\underline{\text { North Central }}$ & & & & \\
\hline Boston & MA & & 1 & 1 & Chicago & IL & 1 & 1 & \\
\hline \multirow[t]{3}{*}{ New Haven } & $\mathrm{CN}$ & & & & Indianapolis & IN & 1 & 1 & \\
\hline & & & & & Cleveland & $\mathrm{OH}$ & & 11 & \\
\hline & & & & & Columbus & $\mathrm{OH}$ & 1 & 1 & \\
\hline Mid Atlantic & & & & & Detroit & MI & 1 & 1 & 1 \\
\hline Newark & NJ & & & & LaCrosse & WI & & & \\
\hline New York & NY & 1 & & 1 & Milwaukee & WI & 1 & 1 & \\
\hline \multirow[t]{3}{*}{ Philadelphia } & PA & & 1 & 1 & & & & & \\
\hline & & & & & $\underline{\text { Plains and Mountains }}$ & & & & \\
\hline & & & & & Hutchinson & $\mathrm{KS}$ & & & \\
\hline South Central & & & & & Kansas City & KS & 1 & 1 & \\
\hline Louisville & KY & & 1 & 1 & Wichita & KS & 1 & 1 & \\
\hline Kansas City & MO & & 1 & 1 & Minneapolis & $\mathrm{MN}$ & & 11 & \\
\hline \multirow[t]{2}{*}{ St. Louis } & MO & & 1 & 1 & St. Paul & $\mathrm{MN}$ & 1 & 1 & \\
\hline & & & & & Denver & $\mathrm{CO}$ & 1 & 1 & 1 \\
\hline$\underline{\text { South }}$ & & & & & $\underline{\text { Pacific }}$ & & & & \\
\hline Montgomery & $\mathrm{AL}$ & & & & Los Angeles & CA & 1 & 1 & 1 \\
\hline New Orleans & LA & & 1 & 1 & Pasadena & $\mathrm{CA}$ & & & \\
\hline Oklahoma City & OK & & 1 & 1 & Portland & OR & & 1 & 1 \\
\hline Tulsa & OK & & 1 & & Ogden & UT & & 1 & \\
\hline \multirow[t]{2}{*}{ Nashville } & $\mathrm{TN}$ & & 1 & 1 & Salt Lake City & UT & 1 & L & 1 \\
\hline & & & & & Seattle & WA & & 1 & 1 \\
\hline
\end{tabular}

Source: Rand McNally Bankers' Directory, July 1930 
Table 3

Correspondents of Banks in Mississippi, 1929

\begin{tabular}{|c|c|c|c|c|c|c|c|c|c|}
\hline \multirow{4}{*}{$\#$} & \multicolumn{8}{|c|}{ Location of Correspondent } & \multirow{4}{*}{$\begin{array}{r}\text { Total } \\
\text { (i) } \\
\end{array}$} \\
\hline & \multirow{3}{*}{$\begin{array}{l}\text { MS } \\
\text { (a) }\end{array}$} & \multirow{3}{*}{$\begin{array}{r}\text { Other } \\
\text { States } \\
\text { (b) } \\
\end{array}$} & \multicolumn{2}{|c|}{ St. Louis } & \multicolumn{2}{|c|}{ Atlanta } & \multirow{3}{*}{$\begin{array}{r}\text { New } \\
\text { Orleans } \\
(\mathrm{g}) \\
\end{array}$} & \multirow{3}{*}{$\begin{array}{r}\text { New } \\
\text { York } \\
(\mathrm{h}) \\
\end{array}$} & \\
\hline & & & $6^{\text {th }}$ & $8^{\text {th }}$ & $6^{\text {th }}$ & 8th & & & \\
\hline & & & (c) & (d) & (e) & (f) & & & \\
\hline 0 & 199 & 7 & 101 & 15 & 3 & 62 & 93 & 104 & \\
\hline 1 & 91 & 56 & 34 & 79 & 54 & 87 & 189 & 197 & 20 \\
\hline 2 & 18 & 85 & 6 & 69 & 64 & 20 & 27 & 9 & 69 \\
\hline 3 & 2 & 76 & & 6 & 19 & & 1 & & 111 \\
\hline 4 & & 83 & & & 1 & & & & 106 \\
\hline 5 & & 4 & & & & & & & 4 \\
\hline $\mathrm{N}$ & 310 & 310 & 141 & 169 & 141 & 169 & 310 & 310 & 310 \\
\hline
\end{tabular}

Source: Rand McNally Bankers’ Directory

Notes: Each column indicates the number of banks in Mississippi which reported $0,1,2,3,4$, or 5 correspondents in the designated area. Column (a), for example, indicates that 199 banks in Mississippi possessed no correspondents in the state and 2 banks in Mississippi possessed 3 correspondents in the state. Column (b) indicates the number of correspondent located in states other than Mississippi. Column (c) indicates the number of correspondents in St. Louis, which contained the headquarters of the $8^{\text {th }}$ Federal Reserve District, possessed by banks located in the $6^{\text {th }}$ Federal Reserve District portion of Mississippi. Column (d) indicates the same number for banks located in the $8^{\text {th }}$ District portion of Mississippi. Column (e) and (f) indicate the number of correspondents in Atlanta, which contained the headquarters of the $6^{\text {th }}$ Federal Reserve District, possessed by banks in the $6^{\text {th }}$ and $8^{\text {th }}$ District respectively. Column (g) indicates the number of correspondents in New Orleans. Column (h) indicates the number of correspondents in New York. Column (i) indicates the total number of correspondents in all areas. 
Table 4

Causes of Suspensions

January 1929 to March 1933

\begin{tabular}{lrrrrrr}
\hline Causes of Suspensions & 1929 & 1930 & 1931 & 1932 & 1933 & Total \\
\hline & 242 & 848 & 1720 & 1125 & 337 & 4272 \\
(a) Assets and Liabilities & 102 & 316 & 457 & 354 & 91 & 1320 \\
(a.1) Assets & 44 & 142 & 294 & 250 & 61 & 791 \\
(a.2) Assets (p) and withdrawals (c) & 16 & 71 & 163 & 74 & 22 & 346 \\
(a.3) Assets (p) and withdrawals (p) & 38 & 145 & 487 & 294 & 116 & 1080 \\
(a.4) Withdrawals (p) and assets (c) & 42 & 174 & 319 & 153 & 47 & 735 \\
(a.5) Withdrawals & 28 & 140 & 97 & 68 & 24 & 357 \\
(b) Closure of correspondent & 143 & 153 & 159 & 76 & 16 & 547 \\
(c) Defalcation and mismanagement & 90 & 215 & 298 & 193 & 91 & 887 \\
(d) Other and multiple causes & & & & & & \\
\hline Total & 503 & 1356 & 2274 & 1462 & 468 & 6063 \\
\hline
\end{tabular}

Note: Statistics for 1933 include only the months January through March. Figures do not include banks closed due to government proclamations, moratoria, or banking holidays. Rows (a.1.1) through (a.1.5) indicate subtotals of line (a.1).

Source: Richardson (2005). 
Table 5

Temporary and Terminal Suspensions by Clearing System and Year January 1929 to March 1933

\begin{tabular}{|c|c|c|c|c|c|c|}
\hline & \multicolumn{2}{|c|}{ Correspondent } & \multicolumn{2}{|c|}{ Clearing } & \multicolumn{2}{|c|}{ Federal Reserve } \\
\hline & $\begin{array}{r}\text { Term. } \\
\text { (a) }\end{array}$ & $\begin{array}{r}\text { Temp. } \\
\text { (b) }\end{array}$ & $\begin{array}{r}\text { Term. } \\
\text { (c) } \\
\end{array}$ & $\begin{array}{r}\text { Temp. } \\
\text { (d) }\end{array}$ & $\begin{array}{r}\text { Term. } \\
(\mathrm{e}) \\
\end{array}$ & $\begin{array}{r}\text { Temp. } \\
\text { (f) }\end{array}$ \\
\hline 1929 & 366 & 62 & 3 & 0 & 64 & 7 \\
\hline 1930 & 874 & 241 & 37 & 6 & 169 & 21 \\
\hline 1931 & 1,461 & 224 & 72 & 10 & 432 & 74 \\
\hline 1932 & 976 & 133 & 37 & 2 & 290 & 27 \\
\hline 1933 & 326 & 41 & 11 & 1 & 83 & 2 \\
\hline Total & 4,003 & 701 & 160 & 19 & 1,038 & 131 \\
\hline \# 1929 & & 14,080 & & 2,183 & & 8,707 \\
\hline$\%$ Suspended & & $33.4 \%$ & & $8.2 \%$ & & $11.9 \%$ \\
\hline$\%$ Failed & & $28.4 \%$ & & $7.3 \%$ & & $13.4 \%$ \\
\hline
\end{tabular}

Source: Rand McNally Bankers' Directory, Historical Statistics of the United States, and National Archives and Records Administration. See data appendix and Richardson (2005) for details of NARA data.

Notes: Columns headed "Term" indicate the number of terminal suspensions. Columns headed "Temp" indicate the number of temporary suspensions. Figures for 1933 include only banks that failed preceding the banking holiday. The row "\# 1929" indicates the number of banks of that type in operation on June 30, 1929. The row "\% Failed" indicates the percentage of banks of that type in operation at the beginning of the depression that suspended operations terminally before the banking holiday in 1933. The row "\% Suspended" indicates the percentage of banks of that type suspended operations either temporarily or terminally before the banking holiday. 
Figure 1

Checks in Transit as a Share of Bankers' Balance for State Commercial Banks 1913 to 1939

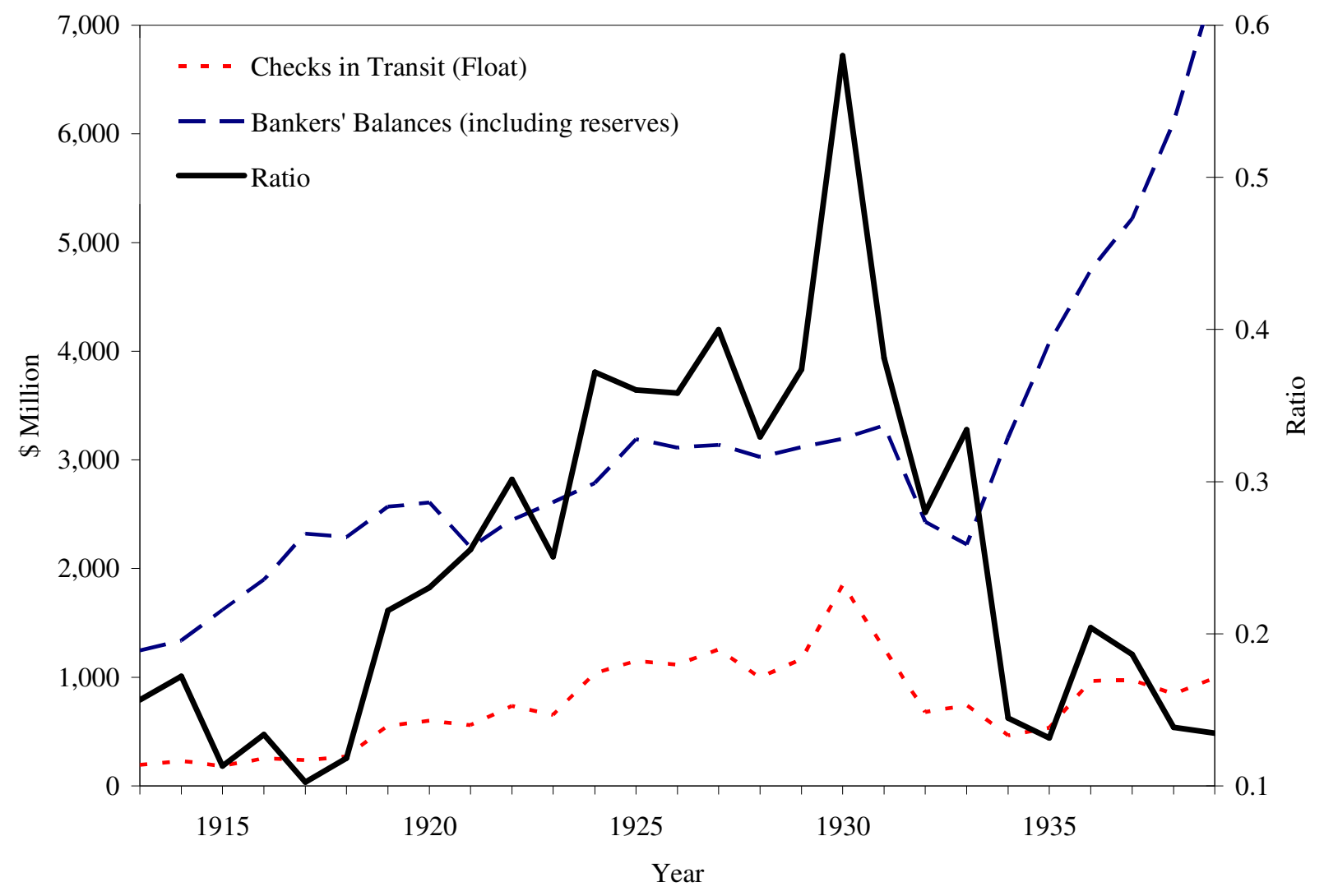

Source: Board of Governors, All Bank Statistics, Table A-3, p. 43, 1959.

Notes: The series were constructed using data from June 30 of each year or the nearest available date. 
Figure 2

Causes of Suspensions, Percent of Totals, January 1929 through March 1933

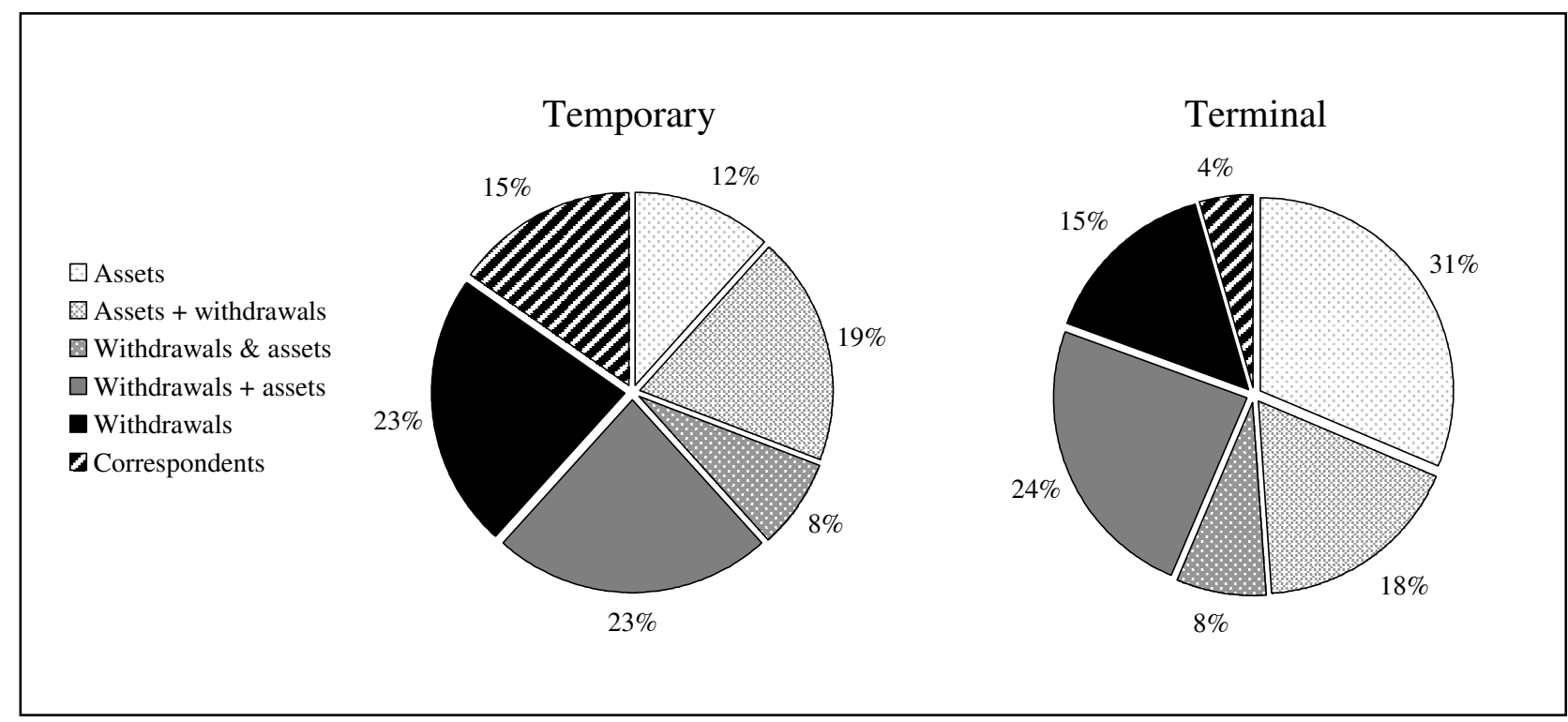

Note: The pie charts above display the proportion of suspensions occurring between January 1929 and March 1933 attributed to the 6 causes listed above. Suspensions attributed to defalcation, mismanagement, multiple, and other causes were excluded from the calculations. The proportions of suspensions attributed to those causes were roughly equal.

Source: Richardson (2005). 
Figure 3

Suspensions Due to Closures of Correspondents, January 1929 through March 1933

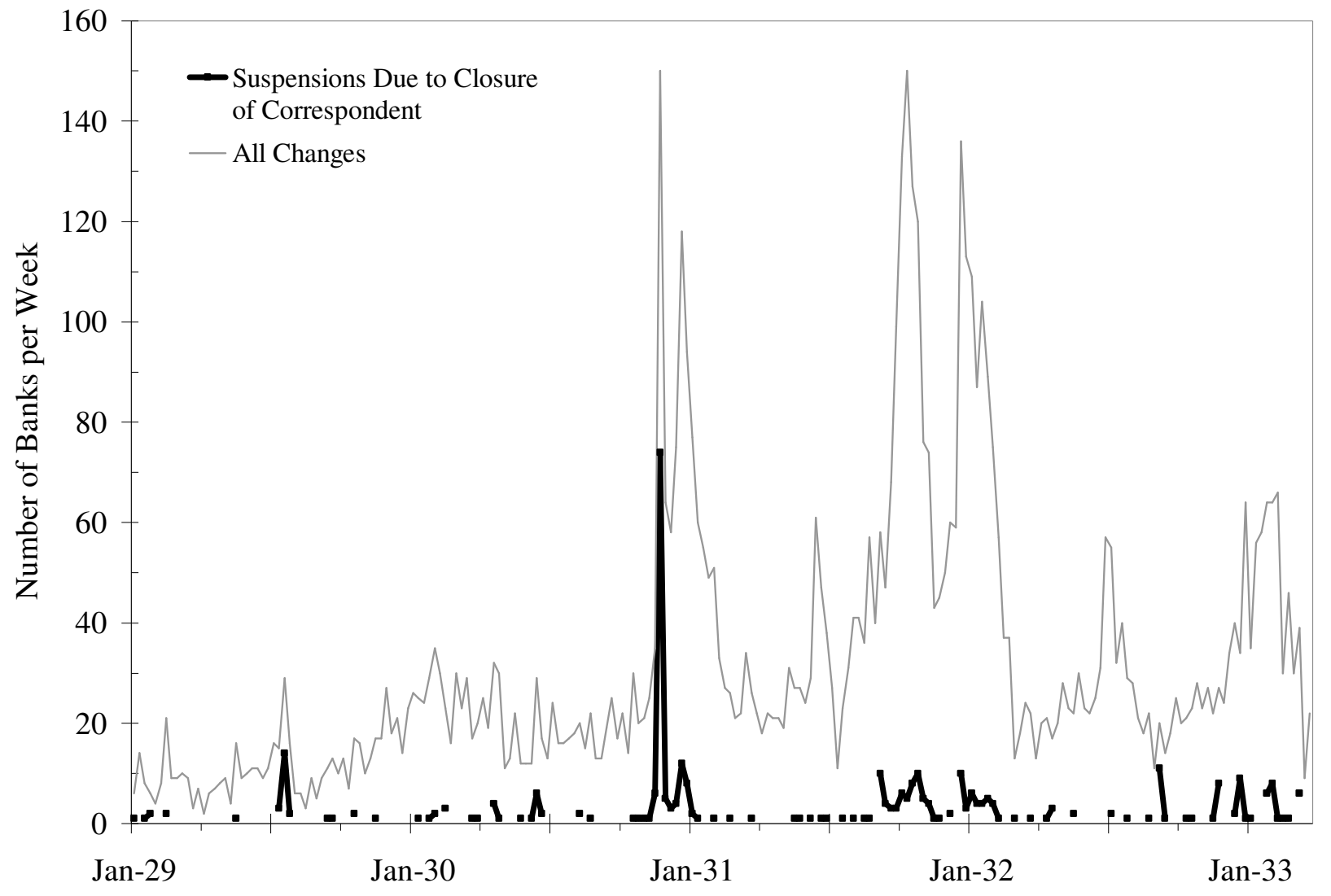

Source: Richardson (2005). 
Figure 4

Causes of Suspension during the First Banking Crisis, September 1930 through March 1931

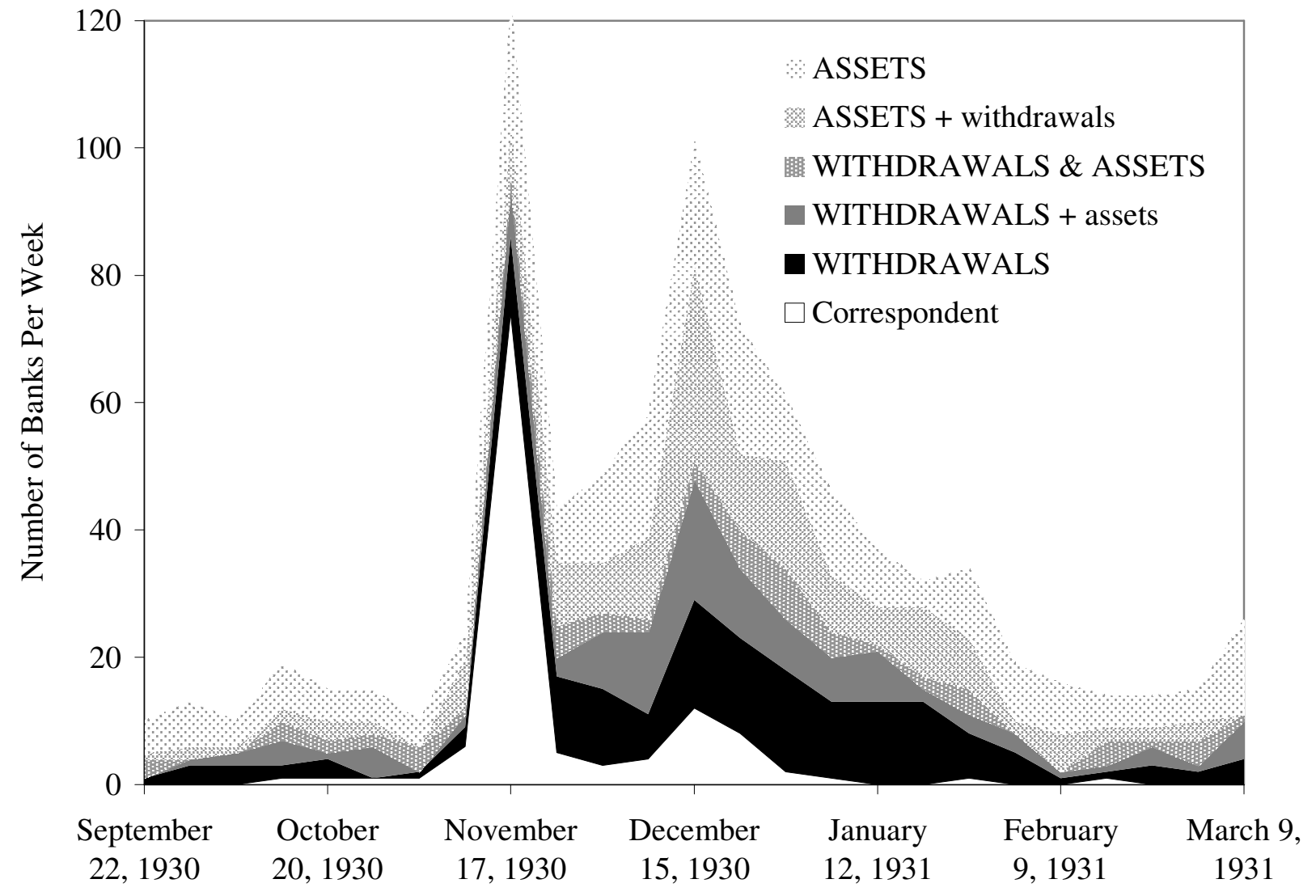

Source: Richardson (2005). 


\section{Bibliography}

Anderson, Gordon B. "Some Phases of the New Check Collection System." Annals of the American Academy of Political and Social Science, Vol. 63, National Industries and the Federal Government, (Jan 1919) pp. 122-131.

Andrews, Fletcher. "The Operation of the City Clearing House." Yale Law Journal, Vol. 51, No. 4 (February 1942), pp. 582-607.

Board of Governors of the Federal Reserve System. 1929. "Memorandum Regarding Preparation of Reports of Changes in Status of Member and Nonmember Banks," Memo: November 18, 1929. National Archives, Record Group 82, Federal Reserve Central Subject File, 421.113.

1930. Committee on Branch, Group and Chain Banking, "Bank Changes - Definitions of Terms," Memo: November 5, 1930. National Archives, Record Group 82, Federal Reserve Central Subject File, 421.113-1.

---- 1931. Committee on Branch, Group and Chain Banking. "Comments Regarding Preparation of Form F." 23 November 1931. National Archives, Record Group 82, Federal Reserve Central Subject File, 421.113-1, Forms and Instructions.

---- $\quad$ 1937. "Bank Suspensions in the United States." Federal Reserve Bulletin. Washington, D.C.: Board of Governors of the Federal Reserve System. September, 1937.

---- $\quad$ Banking and Monetary Statistics, 1914-1941. Washington, D.C.: Federal Reserve System, 1943.

---- $\quad$ All Bank Statistics, 1896-1955. Washington, D.C.: Federal Reserve System, 1959.

Bryan, George. "The Law of Clearing Houses." Virginia Law Review, Vol. 2, No. 6 (March 1915) pp. 447-456.

Calomiris, Charles W. and Joseph R. Mason. "Fundamentals, Panics, and Bank Distress During the Depression." American Economic Review, December 2003, 93(5): pp. 1615-1646.

Christiano, Lawrence J., Roberto Motto, and Massimo Rostagno. "The Great Depression and the Friedman-Schwartz hypothesis,” Working Paper 0318, Federal Reserve Bank of Cleveland. 2004.

Eichengreen, Barry. Golden Fetters. New York: Oxford University Press, 1992.

Friedman, Milton and Schwartz, Anna J. 1971. A Monetary History of the United States, 1867-1960. Princeton: Princeton University Press.

Goldenweiser, E. A., et al. 1931. Bank Suspensions in the United States, 1892-1931. Volume 4. Material prepared for the information of the Federal Reserve System by the Federal Reserve Committee on Branch, Group, and Chain Banking.

Gilbert, R. Alton. "Did the Fed's Founding Improve the Efficiency of the U.S. Payments System?" Federal Reserve Bank of St. Louis Review 77 (1998), pp. 7-23.

Green, Edward and Richard M. Todd. "Thoughts on the Fed's Role in the Payments System." Federal 
Reserve Bank of Minneapolis Quarterly Review (2001) 25, pp. 12-27.

Hamilton, David. "The Causes of the Banking Panic of 1930, Another View." Journal of Southern History November 1985, (51), pp. 581-608.

James, John and David Weiman. "Drafts, Correspondent Banking Networks, and the Transformation of the U.S. Payments System, 1850-1914.” Manuscript. February 2004.

Howard Preston. “The Federal Reserve Banks' System of Par Collections.” Journal of Political Economy. Vol 28, No. 7, (Jul 1920) pp. 565-590.

Lawrence, J. S. "Borrowed Reserves and Bank Expansion." Quarterly Journal of Economics, Vol. 42, No. 4. (Aug 1928) pp. 593-626.

Lucia, Joseph. 1985. "The Failure of the Bank of the United States: A Reappraisal.” Explorations in Economic History 22 (October): 402-16.

McFerrin, James B. 1939. Caldwell and Company. Chapel Hill: University of North Carolina Press.

Meltzer, Allan H. "Monetary and Other Explanations for the Start of the Great Depression." Journal of Monetary Economics 2 (1976): 455-72.

Redenius, Scott A. "Hubs and Spokes: Network Effects and the Formation of Regional Banking Centers." Manuscript: Bryn Mawr College, February 2003.

Richardson, Gary. "The Records of the Federal Reserve Board of Governors in the National Archives of the United States." Financial History Review (forthcoming June 2006).

"Bank Distress During the Great Contraction, 1929 to 1933, New Data From the Archives of the Board of Governors." UC Irvine Mimeo, 2005.

Richardson, Gary and William Troost. "Monetary Intervention Mitigated Banking Panics During the Great Depression: Quasi-Experimental Evidence from the Federal Reserve Border in Mississippi, 1929 to 1933." UC Irvine Mimeo, 2006.

Romer, Christina. "The Nation in Depression.” The Journal of Economic Perspectives. Vol 7, No. 2 (Spring, 1993), pp. 19-39.

Spahr, Walter E. The Clearing and Collection of Checks. New York: Bankers Publishing, 1926.

Talbert, Joseph. "Clearing: House and Domestic: Exchange Functions of the Federal Reserve Banks." Proceedings of the Academy of Political Science in the City of New York, Vol. 4, No. 1, (Oct 1913) pp. 192-212.

Temin, Peter. Did Monetary Forces Cause the Great Depression? New York: W.W. Norton, 1976.

---- Lessons from the Great Depression. Cambridge, MA: MIT Press, 1989.

United States, Bureau of the Census. Historical statistics of the United States, colonial times to 1970. 
Bicentennial Edition. Washington: U.S. Dept. of Commerce, U.S. Govt. Print. Off., 1975

Wheelock, David. "Member Bank Borrowing and the Fed's Contractionary Monetary Policy During the Great Depression." Journal of Money, Credit and Banking November 1990, (22) pp. 409-426.

White, Eugene. 1984. “A Reinterpretation of the Banking Crisis of 1930.” Journal of Economic History 44 (March): 119-38.

White, Eugene N. The Regulation and Reform of the American Banking System, 1900 - 1929. Princeton: Princeton University Press, 1983.

Wicker, Elmus. 1980. “A Reconsideration of the Causes of the Banking Panic of 1930.” Journal of Economic History 40 (September): 571-83.

1996. The Banking Panics of the Great Depression. Cambridge: Cambridge University Press, 1996.

Young, Stanley. "Enlargement of Clearing House Functions." Annals of the American Academy of Political and Social Science, Vol. 36, No. 3, Banking Problems (Nov 1910) pp. 129134. 